\title{
Silencing of StRIK in potato suggests a role in periderm related to RNA processing and stress
}

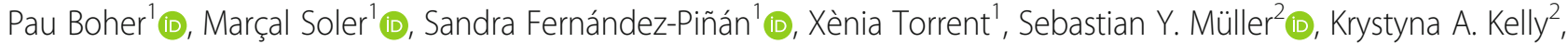 \\ Olga Serra ${ }^{1}$ (i) and Mercè Figueras ${ }^{1 *}$ (i)
}

\begin{abstract}
Background: The periderm is a protective barrier crucial for land plant survival, but little is known about genetic factors involved in its development and regulation. Using a transcriptomic approach in the cork oak (Q. suber) periderm, we previously identified an RS2-INTERACTING KH PROTEIN (RIK) homologue of unknown function containing a $\mathrm{K}$ homology $(\mathrm{KH})$-domain RNA-binding protein, as a regulatory candidate gene in the periderm.

Results: To gain insight into the function of RIK in the periderm, potato (S. tuberosum) tuber periderm was used as a model: the full-length coding sequence of RIK, hereafter referred to as StRIK, was isolated, the transcript profile analyzed and gene silencing in potato performed to analyze the silencing effects on periderm anatomy and transcriptome. The StRIK transcript accumulated in all vegetative tissues studied, including periderm and other suberized tissues such as root and also in wounded tissues. Downregulation of StRIK in potato by RNA interference (StRIK-RNAi) did not show any obvious effects on tuber periderm anatomy but, unlike Wild type, transgenic plants flowered. Global transcript profiling of the StRIK-RNAi periderm did show altered expression of genes associated with RNA metabolism, stress and signaling, mirroring the biological processes found enriched within the in silico co-expression network of the Arabidopsis orthologue.
\end{abstract}

Conclusions: The ubiquitous expression of StRIK transcript, the flower associated phenotype and the differential expression of StRIK-RNAi periderm point out to a general regulatory role of StRIK in diverse plant developmental processes. The transcriptome analysis suggests that StRIK might play roles in RNA maturation and stress response in the periderm.

Keywords: RS2-INTERACTING KH PROTEIN, Potato tuber periderm, Flowering, RNA regulation, KH-domain RNA-binding protein

\section{Background}

Plants cope with ever-changing environmental factors which are sometimes adverse and hinder their survival. To deal with these unfavorable circumstances, plants rely on developmental solutions and regulatory networks to protect their body structure and to optimize their

\footnotetext{
*Correspondence: merce.figueras@udg.edu

'Laboratori del Suro, Biology Department, Universitat de Girona, Campus Montilivi, E-17071 Girona, Catalonia, Spain

Full list of author information is available at the end of the article
}

metabolism and physiology. Among the adaptations that land plants develop, the formation of waterproof barriers is essential to prevent uncontrolled water loss [1] and pathogen attack [2]. This protection is achieved in secondary organs, tubers and wounded tissues by an external barrier known as the periderm. The periderm consists of three different layers from inside to outside: the parenchymatous phelloderm, the meristematic phellogen and the cork or phellem. The phellem confers protection to the periderm through depositing suberin,

(c) The Author(s). 2021, corrected publication 2022. Open Access This article is licensed under a Creative Commons Attribution 4.0 International License, which permits use, sharing, adaptation, distribution and reproduction in any medium or format, as long as you give appropriate credit to the original author(s) and the source, provide a link to the Creative Commons licence, and indicate if changes were made. The images or other third party material in this article are included in the article's Creative Commons licence, unless indicated otherwise in a credit line to the material. If material is not included in the article's Creative Commons licence and your intended use is not permitted by statutory regulation or exceeds the permitted use, you will need to obtain permission directly from the copyright holder. To view a copy of this licence, visit http://creativecommons.org/licenses/by/4.0/ The Creative Commons Public Domain Dedication waiver (http://creativecommons.org/publicdomain/zero/1.0/) applies to the data made available in this article, unless otherwise stated in a credit line to the data. 
lignin and associated-waxes within the cell walls [3]. Despite the importance of periderm ontogenesis for land plant survival, the molecular networks that regulate its formation and differentiation are little known. Several transcriptomic studies have used cork tissue [4-12] resulting in a substantial list of candidate regulatory proteins including phytohormone-related proteins, signal transductors and transcriptional regulators. Several transcription factors were shown to be relevant in periderm for suberin deposition: StNAC103, QsMYB1 and ANAC046 [13-16]. StNAC103 was suggested as a repressor of suberin and associated waxes in potato tuber periderm [15, 16], while QsMYB1 and ANAC046 were proposed as inducers of suberin deposition in cork oak (Q. suber) bark and Arabidopsis root periderm, respectively $[13,14]$.

In a previous transcriptomic study in cork oak, a gene homologous to the maize RS2-INTERACTING KH PROTEIN (RIK) [17] was upregulated in cork compared to xylem tissue [7]. The RIK protein interacted with the maize gene rough sheath2 ( $r s 2$ ), the orthologue of Arabidopsis ASYMMETRIC LEAVES 1 (AS1) which forms conserved complexes with ASYMMETRIC LEAVES 2 (AS2) and the histone chaperone HIRA [17]. The AS1/ AS2/HIRA complex maintains the silencing of class I KNOX genes through a repressed chromatin state, promoting stem cell activity and meristem maintenance to form determinate lateral organs [17-20]. It was hypothesized that RIK could contribute to the epigenetic repression of KNOX genes in the AS1/AS2/HIRA complex by binding of regulatory RNAs [17], although the function of the RIK protein remains to be experimentally determined. Sequence analysis of RIK revealed that it contains a K-homology $(\mathrm{KH})$ RNA binding domain and a like helicase domain (LHD) [17]. KH domain-containing proteins are RNA binding proteins known to be involved in splicing, regulation of post-transcriptional gene expression, mRNA stability, miRNA biogenesis and heterochromatin silencing [21, 22]. The RIK protein is encoded by a single gene in Arabidopsis, maize and rice and has a Splicing Factor 1-like KH domain, although the canonical core sequence of $\mathrm{KH}$ domain is weakly conserved among the RIK proteins [23]. The phylogenetic tree shows that RIK proteins form a distinct clade, distinguished from all other SF1-like $\mathrm{KH}$ and $\mathrm{KH}$ proteins. Although the RIK transcript accumulates in all tissues analyzed in maize, a higher level of mRNA accumulation was shown in the shoot apical meristem and a lower level in older leaves [23]. In plants, several studies have demonstrated that $\mathrm{KH}$ domain proteins influence flower development [24-26], vegetative growth [27], stress tolerance [28] and jasmonate signaling [29].

Here, to get closer to the function of the potato StRIK gene in periderm, StRIK was stably silenced and the tuber periderm anatomy and transcriptome were analyzed. StRIK downregulation affected the expression of genes related to RNA metabolism, stress response and signaling in tuber periderm.

\section{Results}

StRIK and its orthologues show two SF1_like-KH domains The StRIK protein sequence, translated from the cDNA sequence isolated from $S$. tuberosum Group Tuberosum cv Désirée, shows significant homology $(98.82,97.85$, 97.85, 98.13\% identities) with the four protein isoforms encoded in PGSC0003DMG400025145 locus (corresponding to PGSC0003DMP400043638, PGSC0003DMP400043639, PGSC0003DMP400043637, PGSC0003DMP400043640, respectively) from the S. tuberosum Group Phureja genome [30]. The Conserved Domain Database [31] identified two SF1-like KH (cd02395) domains located between the amino acids 127-203 (e-value $1.38 \mathrm{e}^{-04}$ ) and 216-291 (e-value $1.77 \mathrm{e}^{-04}$ ) (Fig. S1). As shown in Fig. S1, the KH domain core sequence is highly conserved amongst all the RIK proteins included in the alignment (V/IRGPNDQYI) but, as it occurs in the maize RIK protein [23], it is weakly conserved with the canonical IIGxxGxxI core sequence of the $\mathrm{KH}$ domains [21].

\section{StRIK transcript is ubiquitous}

The transcript profile of $S t R I K$ in potato tissues analyzed by RT-qPCR showed high transcript levels in root, stem, leaf, tuber flesh and tuber periderm (Fig. S2A). These results confirmed the ubiquitous expression of the gene found in the RNA-seq data available from the S. tuberosum Group Phureja [30], which also revealed moderate gene induction in flower organs (flower, petiole and stamen), in root and in tissues with meristematic activity (shoot apex, tuber sprout) (Fig. S2B). Moreover, S. phureja $R I K$ is induced by abiotic stresses such as mannitol (osmotic stress), water-stressed leaves, salt and abscisic acid (ABA) treatments while it is downregulated upon heat and cytokinin (BAP; benzyl adenine) treatments (Fig. S2B). The effect of wounding (see Plant Material subsection) on transcript abundance of StRIK was analyzed. According to the regression analysis there was a highly significant linear increase in StRIK levels after wounding $(p<0.001)$ (Fig. S2C).

\section{StRIK is located in the nucleus}

The subcellular localization of StRIK protein was determined in N. benthamiana by transient Agrobacteriummediated leaf transformation to yield StRIK tagged with RFP to the $\mathrm{N}$-terminal end. After $72 \mathrm{~h}$ of infection, a red fluorescence, indicative of the StRIK protein accumulation, was detected concentrated in a single spot showing the typical pattern of nuclear located proteins with the 
gap free of labeling corresponding to the nucleolus (Fig. 1) [32].

\section{StRIK silencing does not affect phellem anatomy but induces flowering}

To evaluate the contribution of StRIK to phellem formation, StRIK was silenced using RNAi (Fig. S3). A $246 \mathrm{bp}$ fragment spanning the nucleotides 758 to 1003 of the StRIK coding sequence (Genbank accession number: MT622318) was used, which overlaps partially or completely with exons 8,9 and 10 of the gene (Fig. S4). To check the possibility of off-target silencing we performed a BLASTN analysis using the silencing RNAi sequence as query against the Potato Genome Database [30] setting the expected threshold parameter to 1 . The analysis identified the representative transcript (PGSC0003DMT400064730) and two transcript isoforms of RIK as RNAi-targets (PGSC0003DMT400064729 and PGSC0003DMT400064731), while the fourth and shortest predicted RIK transcript isoform (PGSC0003DMT400064735) was not identified because is not targeted by the RNAi fragment (Fig. S4 and Table S1). The other transcripts identified by the BLASTN analysis showed a partial match in 18 or less consecutive nucleotides, hence cross-silencing was unlikely.

Twenty independent transformation events producing StRIK-RNAi kanamycin-resistant potato plants were analyzed by RT-qPCR. Five transgenic lines displayed a reduction in StRIK transcript levels in leaves (Fig. S5a) and tuber periderm (Fig. S5b). The StRIK-RNAi lines 9, 12, and 47 were propagated to produce enough tubers for subsequent phenotypic and transcriptomic analyses. The RT-qPCR was repeated in these three lines and the silencing of StRIK in periderm was confirmed (Fig. 2). When five StRIK-RNAi plants from each of the three lines (line 9, 12 and 47) were grown in soil under longday conditions ( $12 \mathrm{~h}$ light $/ 12 \mathrm{~h}$ dark), $53.3 \%$ of them flowered whereas, as expected, none of the Wild type $(0$ out of 10) flowered because the Désirée cultivar does not flower in our growth conditions (Fig. 3a). Evident floral transition at the shoot apical meristem was observed in the StRIK-RNAi lines unlike Wild type (Fig. 3b compared with Fig. 3a), and fully developed flowers were formed (Fig. 3d compared with Fig. 3c). The anatomy of the potato periderm was investigated in Wild type and StRIK silenced lines of 21-d stored tubers. Scanning Electron Microscopy (SEM) did not reveal obvious differences in the number of cell layers or in the general cellular architecture (Fig. 4).

The periderm transcriptome comparison shows that StRIK silencing affects RNA metabolism, transposon- and stressrelated genes

To explore the effects of StRIK silencing on the global transcription profile, the periderm RNA from three replicates of each of the three StRIK-RNAi lines (lines 9, 12 and 47) and Wild type potato tubers was extracted and sequenced using an Illumina HiSeq2000. Reads were mapped to the potato transcriptome and the number of reads per transcript was quantified. To identify those genes showing differential expression between StRIK silenced and Wild type plants, we used the six StRIKRNAi libraries where the StRIK abundance was less than two thirds that of the Wild type (line $9 n=1$, line $12 n=$ 2; line $47 n=3$ ). A total of 101 differentially expressed genes (DEGs) were identified, 66 genes were upregulated and 35 genes were downregulated in StRIK-RNAi lines (Table S2). Using the potato gene identifier, Uniref100 (downloaded on 16/06/2017) (Suzek et al., 2007) and TAIR (Arabidopsis Information Resource (https://www. arabidopsis.org/)), functional annotations were retrieved through the Spud DB Potato Genomics Resources (http://solanaceae.plantbiology.msu.edu/pgsc_download. shtml) [30]. Taking advantage of the information in
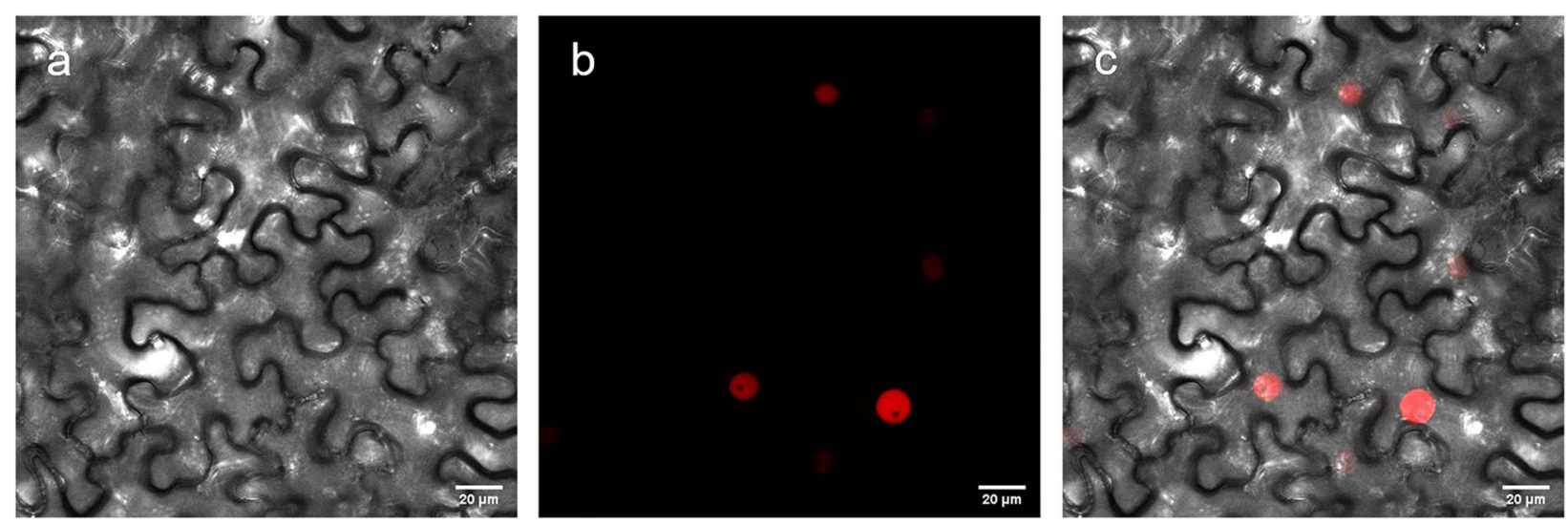

Fig. 1 Subcellular localization of RFP-StRIK in N. benthamiana leaf. Micrographs obtained of a) bright field, b) red fluorescence channel and c) overlay of bright field and red fluorescence channel 


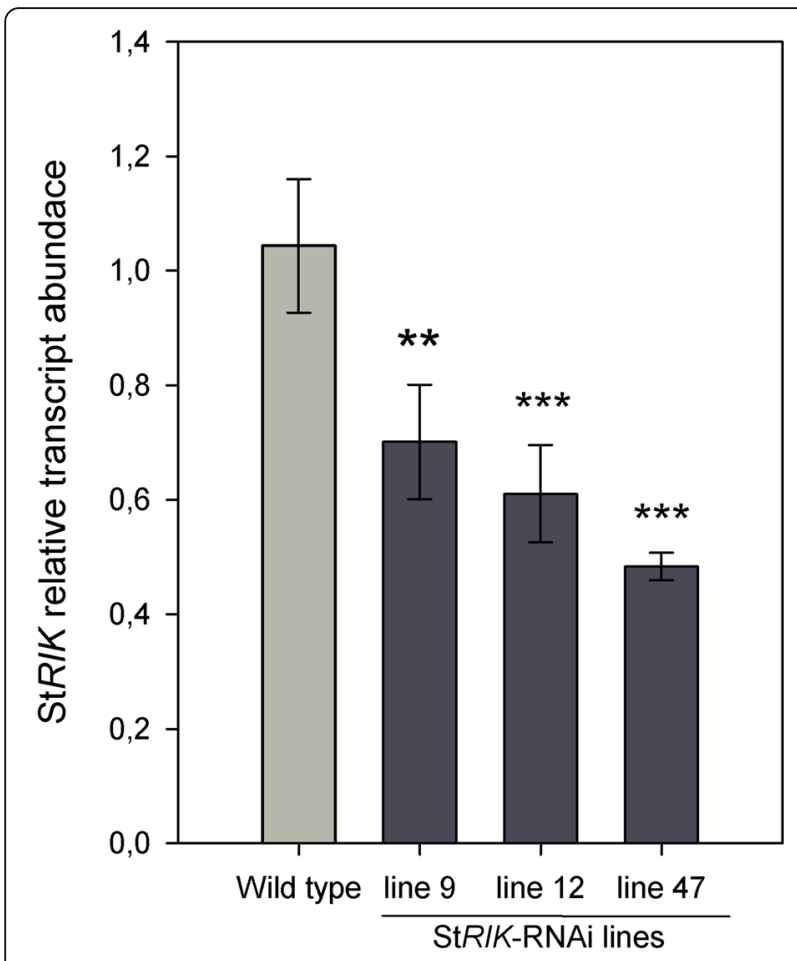

Fig. 2 StRIK transcript accumulation in the periderm of Wild type and StRIK-RNAi lines. Three independent transformation events were analyzed (lines 9, 12 and 47) and for each line, three biological replicates were used. For each biological replicate, we used three technical replicates (Dunnett's test for comparing multiple groups to a control was used (two asterisks (**, $P<0.01$ ), three asterisks $(* * *, P<0.001))$

these Genomic Resources, the DEGs were classified manually into functional categories. DEGs showing $\log _{2} \mathrm{FC}$ values $\leq-2$ and $\geq 2$ in the main functional groups identified are shown in Table 1. The biological processes dominated by genes upregulated in StRIKRNAi lines were RNA metabolism, proteolysis and metabolism while stress, transposable elements and signaling were biological processes with similar numbers of up and downregulated genes in the StRIK-RNAi lines (Table S2).

To validate the RNA-seq results, the relative expression of five DEGs was analyzed by RT-qPCR in periderm from StRIK-RNAi (lines 12 and 47) and Wild type tubers grown at a different time to those used for the RNA-seq (Fig. 5a). The differential expression of the genes analyzed by RT-qPCR confirmed (Fig. 5a) the RNA-seq findings (Fig. 5b).

The biological processes identified in the co-expression network of Arabidopsis RIK correlate with the transcriptome of StRIK-RNAi periderm

We explored the co-expression network of the Arabidopsis RIK gene by selecting the 300 genes most co- expressed with RIK protein based on ATTED-II (https:// atted.jp/ [33];). Among the top 50 co-expressed genes, there were splicing factors (e.g. PWI domain-containing protein, CC1-like), two flowering time gene (FCA, EDM2), development genes (TTL, cyclin-related, REV1), other $\mathrm{KH}$ domain-containing proteins (e.g. At3g32940, At4g10070) and a microRNA (MIR834a) (Table S3). The gene ontology (GO) enrichment of these 300 coexpressed genes in the PlantGSEA database [34] highlighted processes related to RNA metabolism (e.g. 'mRNA processing' 'RNA metabolic process', 'poly(A) RNA binding'), RNA splicing (e.g. 'RNA splicing', 'mRNA splicing, via spliceosome', 'RNA splicing, via transesterification reactions'), regulation (e.g. 'regulation of gene expression', 'regulation of biological process'), gene silencing (e.g. 'gene silencing', 'gene silencing by RNA') and development (e.g. 'post-embryonic development', 'vegetative to reproductive phase transition of meristem', 'flower development'). Several GO terms related to the nucleus and spliceosome were identified within the cellular component classes (Table S4).

\section{Discussion}

The potato StRIK gene, as well as its orthologues in Arabidopsis (At3g29390) and maize, are genes of unknown function. They are putative RNA-binding polypeptides with a K-homology $(\mathrm{KH})$ domain. Our results showed StRIK ubiquitous expression in different plant tissues at similar levels (Fig. S2), which is in accordance with the S. phureja RIK RNA-seq data extracted from the PGSC [30] and with the transcript profile of its orthologue in maize [23]. Although Soler et al. [7] reported upregulation of the cork oak QsRIK gene in phellem compared with xylem $(\mathrm{FC}=5)$, the present work suggests that the role of this potato gene is not specific to phellem or suberized tissues. Potato and Arabidopsis RIK genes are upregulated in flowers, fruits and in the shoot apex inflorescence during floral transition (Fig. S2). We found that StRIK-RNAi plants displayed floral transition in the shoot apical meristem and mostly formed fully developed flowers whereas Wild type plants did not, despite growing in parallel under the same conditions (Fig. 3ad). This phenotype suggests that downregulation of StRIK could be required for organ specification or tissue differentiation and therefore a repressor role of StRIK in flower development could be hypothesized. Several proteins containing the $\mathrm{K}$ homology $(\mathrm{KH})$ domain have been shown to affect flowering in Arabidopsis [35]. Specifically, the protein HEN4 was involved in the premRNA processing of the AGAMOUS floral homeotic gene [24]; FLK inactivation triggered FLC upregulation, possibly by modulating posttranscriptional gene regulation of FLC [25]; and the PEPPER $\mathrm{KH}$-domain protein was shown to affect pistil development [27]. Its 
Ratio of plants showing floral meristem (FM) at the shoot apical meristem.

\begin{tabular}{cc}
\hline Wild type and StRIK-RNAi lines & plants with FM $/$ total plants \\
\hline Wild type & $0 / 10$ \\
line 9 & $2 / 5$ \\
line 12 & $3 / 5$ \\
line 47 & $3 / 5$ \\
\hline
\end{tabular}
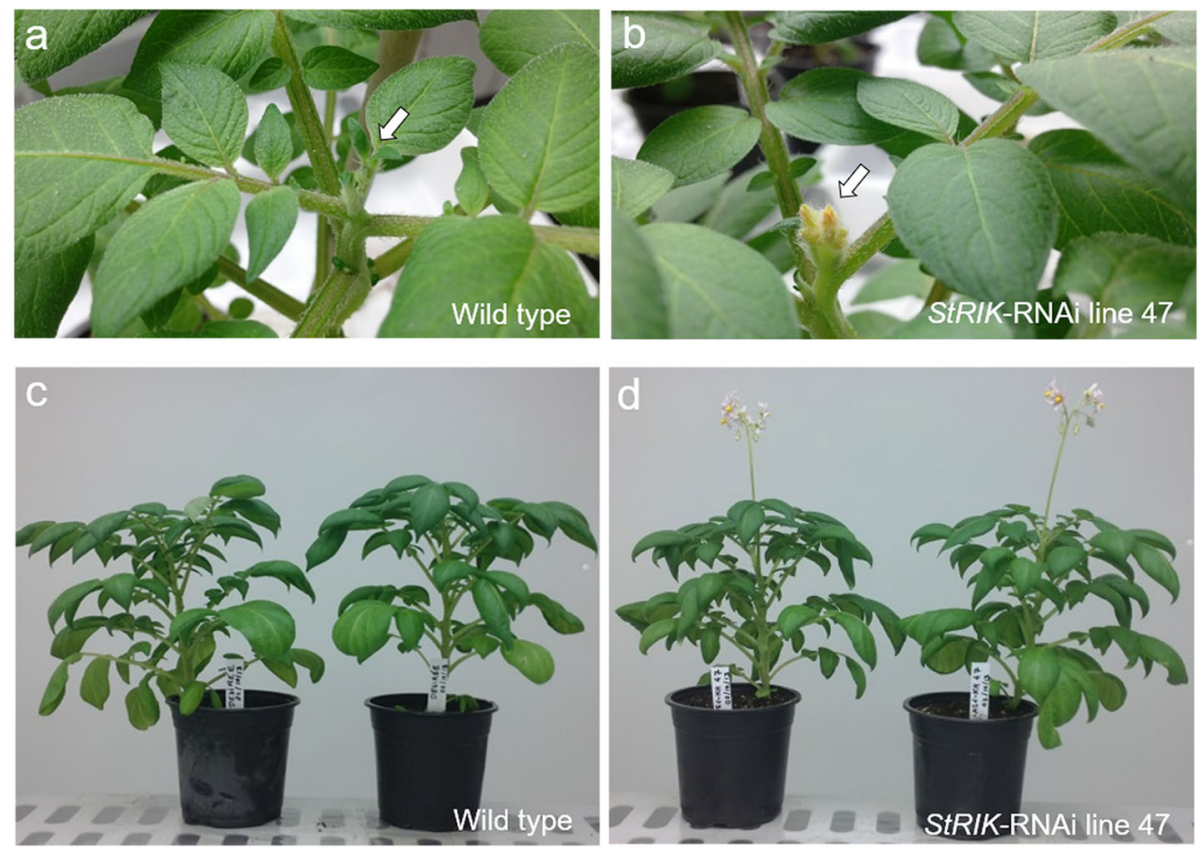

Fig. 3 Effects of StRIK silencing in flower development. Ratio of plants showing flower meristem (FM) per total plants for Wild type and StRIK silenced lines. The arrows point to the detail of $\mathbf{a}$ ) the shoot apical meristem in Wild type plant and $\mathbf{b}$ ) the flower meristem in StRIK-RNAi line. Full view of adult potato plants showing differences in their flowering capacity between $\mathbf{c}$ ) the Wild type and $\mathbf{d}$ ) StRIK-RNAi lines. The co-authors are the owners of the images

overexpression induced an increase of $F L C$ transcript levels and a flowering delay, presumably by transcriptional and posttranscriptional regulatory mechanisms [36]. However, S. phureja RIK is induced in young growing tissues such as stolon and tuber sprout (Fig. S2). This and the ubiquitous gene expression (Fig. S2), suggest that StRIK plays a regulatory role in plant development other than flowering.
There is an upregulation of StRIK after wounding in potato tuber discs (Fig. S2). and the S. phureja RIK shows increased transcript accumulation upon osmotic stress (mannitol), salt stress, ABA treatment and during leaf senescence, but is repressed by heat treatment and wounding (24 $\mathrm{h}$ after wounding in leaves) (Fig. S2). In contrast, in Arabidopsis, wounding induces a mild $R I K$ transcript accumulation in root 3, 6, 12 and $24 \mathrm{~h}$ after injury [37].
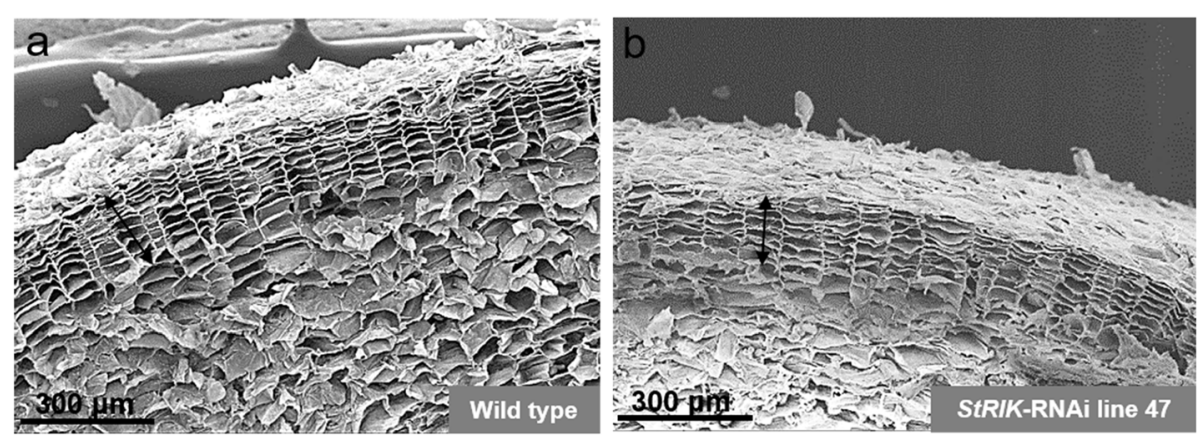

Fig. 4 Effects of StRIK silencing in periderm anatomy. SEM micrograph of tuber periderm cross-section of a) Wild type and $\mathbf{b})$ StRIK-RNAi lines. Similar number of cell layers and phellem organization was observed in both lines. Phellem is shown with a black arrow 
Table 1 DEGs between Wild type (WT) and StRIK-RNAi (RIK) tuber periderm

\begin{tabular}{|c|c|c|c|c|c|}
\hline \multirow[t]{2}{*}{ Functional group } & \multicolumn{2}{|c|}{ Normalized reads } & \multirow[t]{2}{*}{$\mathrm{DE}$} & \multirow[t]{2}{*}{ Uniref gene Description } & \multirow{2}{*}{$\begin{array}{l}\text { Best } \\
\text { BLASTP } \\
\text { TAIR }\end{array}$} \\
\hline & WT (1) & StRIK-RNAi (2) & & & \\
\hline \multicolumn{6}{|l|}{ RNA metabolism } \\
\hline PGSC0003DMT400063700 & 47 & 747 & $2>1$ & RNase $\mathrm{H}$ family protein & AT5G35695 \\
\hline PGSC0003DMT400071451 & 63 & 729 & $2>1$ & RRNA intron-encoded homing endonuclease & - \\
\hline PGSC0003DMT400091537 & 280 & 2636 & $2>1$ & RRNA intron-encoded homing endonuclease & - \\
\hline PGSC0003DMT400085242 & 214 & 2014 & $2>1$ & RRNA intron-encoded homing endonuclease & - \\
\hline PGSC0003DMT400079124 & 0 & 3 & $2>1$ & RNA recognition motif-containing protein & AT5G19030 \\
\hline PGSC0003DMT400063698 & 0 & 15 & $2>1$ & RNase $\mathrm{H}$ family protein & - \\
\hline PGSC0003DMT400094705 & 509 & 6089 & $2>1$ & RRNA intron-encoded homing endonuclease & - \\
\hline \multicolumn{6}{|c|}{ Transposable elements (TE)-related genes } \\
\hline PGSC0003DMT400046437 & 20 & 1 & $1>2$ & TNP2, partial & - \\
\hline PGSC0003DMT400041204 & 34 & 485 & $2>1$ & Retrotransposon protein & AT5G41980 \\
\hline PGSC0003DMT400092517 & 47 & 1 & $1>2$ & $\begin{array}{l}\text { LINE-type retrotransposon LIb DNA, complete } \\
\text { sequence, Insertion at the S14 site }\end{array}$ & - \\
\hline PGSC0003DMT400085583 & 0 & 5 & $2>1$ & Transposon MuDR mudrA & - \\
\hline PGSC0003DMT400039369 & 1188 & 296 & $1>2$ & Transposase & - \\
\hline PGSC0003DMT400003803 & 6 & 92 & $2>1$ & Transposase & AT1G43722 \\
\hline \multicolumn{6}{|l|}{ Stress } \\
\hline PGSC0003DMT400083063 & 1 & 48 & $2>1$ & Ribulose bisphosphate carboxylase large chain & ATCG00490 \\
\hline PGSC0003DMT400026705 & 3 & 30 & $2>1$ & 115 globulin isoform 4 & AT5G44120 \\
\hline PGSC0003DMT400080875 & 2528 & 27100 & $2>1$ & Senescence-associated protein & - \\
\hline PGSC0003DMT400013091 & 0 & 4 & $2>1$ & PR-1 & AT3G19690 \\
\hline PGSC0003DMT400005448 & 0 & 5 & $2>1$ & Vacuolar H+-pyrophosphatase & AT1G15690 \\
\hline PGSC0003DMT400024872 & 0 & 12 & $2>1$ & K+ channel inward rectifying & AT5G46240 \\
\hline PGSC0003DMT400061541 & 3 & 60 & $2>1$ & Dehydration responsive element binding protein & AT5G05410 \\
\hline \multicolumn{6}{|l|}{ Proteolysis } \\
\hline PGSC0003DMT400026261 & 316 & 3520 & $2>1$ & $\mathrm{Nb}$ cell deth marker & AT1G17860 \\
\hline PGSC0003DMT400026262 & 439 & 6499 & $2>1$ & Conserved gene of unknown function & AT1G17860 \\
\hline PGSC0003DMT400024552 & 3 & 38 & $2>1$ & Gene of unknown function & AT1G50690 \\
\hline PGSC0003DMT400049320 & 0 & 4 & $2>1$ & $\begin{array}{l}\text { Ulp1 protease family, C-terminal catalytic domain } \\
\text { containing protein }\end{array}$ & - \\
\hline PGSC0003DMT400040325 & 16 & 2 & $1>2$ & F-box family protein & AT3G07870 \\
\hline \multicolumn{6}{|l|}{ Signaling } \\
\hline PGSC0003DMT400047864 & 5 & 37 & $2>1$ & Signal transducer & AT1G67900 \\
\hline PGSC0003DMT400001990 & 2 & 8 & $2>1$ & Calcium/calmodulin-dependent protein kinase CaMK3 & AT3G50530 \\
\hline PGSC0003DMT400047866 & 16 & 79 & $2>1$ & Signal transducer & AT1G67900 \\
\hline PGSC0003DMT400054991 & 0 & 4 & $2>1$ & Calcium-dependent protein kinase 20 & AT2G38910 \\
\hline PGSC0003DMT400047867 & 14 & 71 & $2>1$ & Signal transducer & AT1G67900 \\
\hline \multicolumn{6}{|l|}{ Metabolism } \\
\hline PGSC0003DMT400052839 & 1 & 18 & $2>1$ & Beta-amylase PCT-BMYI & AT4G17090 \\
\hline PGSC0003DMT400049003 & 686 & 12004 & $2>1$ & Cytochrome P450 like_TBP & - \\
\hline PGSC0003DMT400070122 & 5 & 26 & $2>1$ & Glucosyltransferase & AT4G36770 \\
\hline PGSC0003DMT400014902 & 3 & 0 & $1>2$ & Cytochrome P450 & AT1G12740 \\
\hline PGSC0003DMT400019561 & 0 & 5 & $2>1$ & Cytochrome P450 & AT5G36110 \\
\hline
\end{tabular}


Table 1 DEGs between Wild type (WT) and StRIK-RNAi (RIK) tuber periderm (Continued)

\begin{tabular}{|c|c|c|c|c|c|}
\hline \multirow[t]{2}{*}{ Functional group } & \multicolumn{2}{|c|}{ Normalized reads } & \multirow[t]{2}{*}{ DE } & \multirow[t]{2}{*}{ Uniref gene Description } & \multirow{2}{*}{$\begin{array}{l}\text { Best } \\
\text { BLASTP } \\
\text { TAIR }\end{array}$} \\
\hline & WT (1) & StRIK-RNAi (2) & & & \\
\hline \multicolumn{6}{|l|}{ Acyl lipid Metabolism } \\
\hline PGSC0003DMT400042102 & 1 & 10 & $2>1$ & $\begin{array}{l}\text { Acetyl-coenzyme A carboxylase carboxyl } \\
\text { transferase alpha }\end{array}$ & AT2G3804C \\
\hline PGSC0003DMT400079076 & 0 & 3 & $2>1$ & Acyl-[acyl-carrier-protein] desaturase & AT1G43800 \\
\hline
\end{tabular}

List of genes showing $\log _{2}$ FC values $\leq-2$ and $\geq 2$ classified in the main functional groups. For each gene the mean of normalized reads (effective counts) found in Wild type replicates $(n=3$ ) and StRIK-RNAi (line $9 n=1$; line $12 n=2$; line $47 n=3$ ) is shown. Also, it is reported the potato gene identifier, the Uniref gene identifier and the best BLASTP in TAIR (e value $\leq 10^{-5}$ )

Similarly, the expression of genes involved in response to stress was altered when StRIK was silenced in the tuber periderm. Six genes whose Arabidopsis orthologues are involved in response to $\mathrm{ABA}$ and water deprivation (potato annotation: dehydrin, 11S globulin, dehydration responsive element binding protein, $\mathrm{K}+$ channel inward rectifying, ribulose bisphosphate carboxylase large chain, vacuolar $\mathrm{H}+$-pyrophosphatase, Table 1, Table S2, Fig. 5) were upregulated in StRIKRNAi periderm. For instance, in Arabidopsis, the dehydration responsive element binding protein was related to drought, salt and heat stress responses [38], and the $\mathrm{K}$-channel was involved in potassium cell homeostasis and ABA signal transduction $[39,40]$. Conversely, other abiotic stress genes were downregulated, such as a wound responsive protein, a heat shock binding protein, a metallothionein and the LOB domain-containing protein 41 , a transcription factor known to be induced by hypoxia in Arabidopsis [41] (Table 1, Table S2). Finally, three biotic stress genes were upregulated in these lines: one pathogenesis related and two orthologues to a member of Kunitz trypsin inhibitors (KTI) (At1g17860) (Table S2, stress and proteolysis categories), which play prominent roles in defense response against herbivores and in the response to wounding and methyl jasmonate [42-44]. It is worth to remark that biotic and abiotic stress response were identified in transcriptomic and proteomic approaches in potato tuber periderm $[45,46]$ and lately it was reported that ABA triggers suberin accumulation in the endodermis [47] and is relevant for periderm development [8]. Altogether suggests that StRIK could be significant for cork development related with biotic and abiotic stress signaling.

It is remarkable that most genes related to RNA metabolism are upregulated in StRIK silenced periderm. There are several RNase $\mathrm{H}$ proteins with unknown function in plants, but with pivotal roles in mammalian cell physiology and health, related to genome stability and cell viability [48,49]. Other upregulated genes were a RNA-binding protein encoding for a chloroplast enzyme involved in rRNA maturation and intron recycling (At3g13740, [50]), a gene involved in splicing (At2g16860, [51]) and several rRNA intron-encoded homing endonucleases (Table 1, Fig. 5, Table S2). Accordingly, the co-expression network of the Arabidopsis RIK gene was enriched in several ontologies related to RNA metabolism and splicing (Table S3 and S4). The co-expressed genes included $F C A$, a controlling flowering gene [52] and a splicing factor $U 2 A F 65 A$, involved in intron recognition in plants $[53,54]$ and with capacity to regulate flowering time [55]. Also, RIK co-expressed with two $\mathrm{KH}$-domain RNA binding proteins, SHINY and HOS5, which mediate correct pre-mRNA processing of stress-related genes under stress [28, 56]. Altogether, the DEGs related to stress and RNA metabolism and the co-expression network of Arabidopsis RIK suggest that StRIK could have a role in the periderm by interfering with the genome stability and/or mRNA maturation/stability, and stress signaling pathway.

Among the DEGs it is of note to mention several genes related to DNA transposition which were both up and downregulated in StRIK-RNAi lines (Table 1, Fig. 5 and Table S2). Transposable elements (TE) are mobile genetic elements abundant in genomes, which, upon activation, can alter gene expression [57] triggering effects in plant physiology, development or stress responses [58]. Because uncontrolled transposition is often deleterious, plants have evolved mechanisms to silence the transposons [59] through small interfering RNAs (siRNAs) responsible for RNA-directed DNA methylation (RdDM) [57]. Considering that RIK may bind regulatory RNAs [17] and that gene silencing is a process enriched in the RIK co-expression network (Table S4), it is tempting to speculate that StRIK may contribute to the epigenetic control of TEs during plant development and under stress conditions.

The role of StRIK in phellem remains unknown as its silencing does not affect phellem anatomy (Fig. 4) or the known suberin genes [60]. However, CYP87A2, that was downregulated in StRIK-RNAi periderm, was also identified as a phellem formation candidate because it is upregulated in cork compared with wood [7]. In addition, CASPL4D2, with unknown function, was also downregulated in StRIK- 


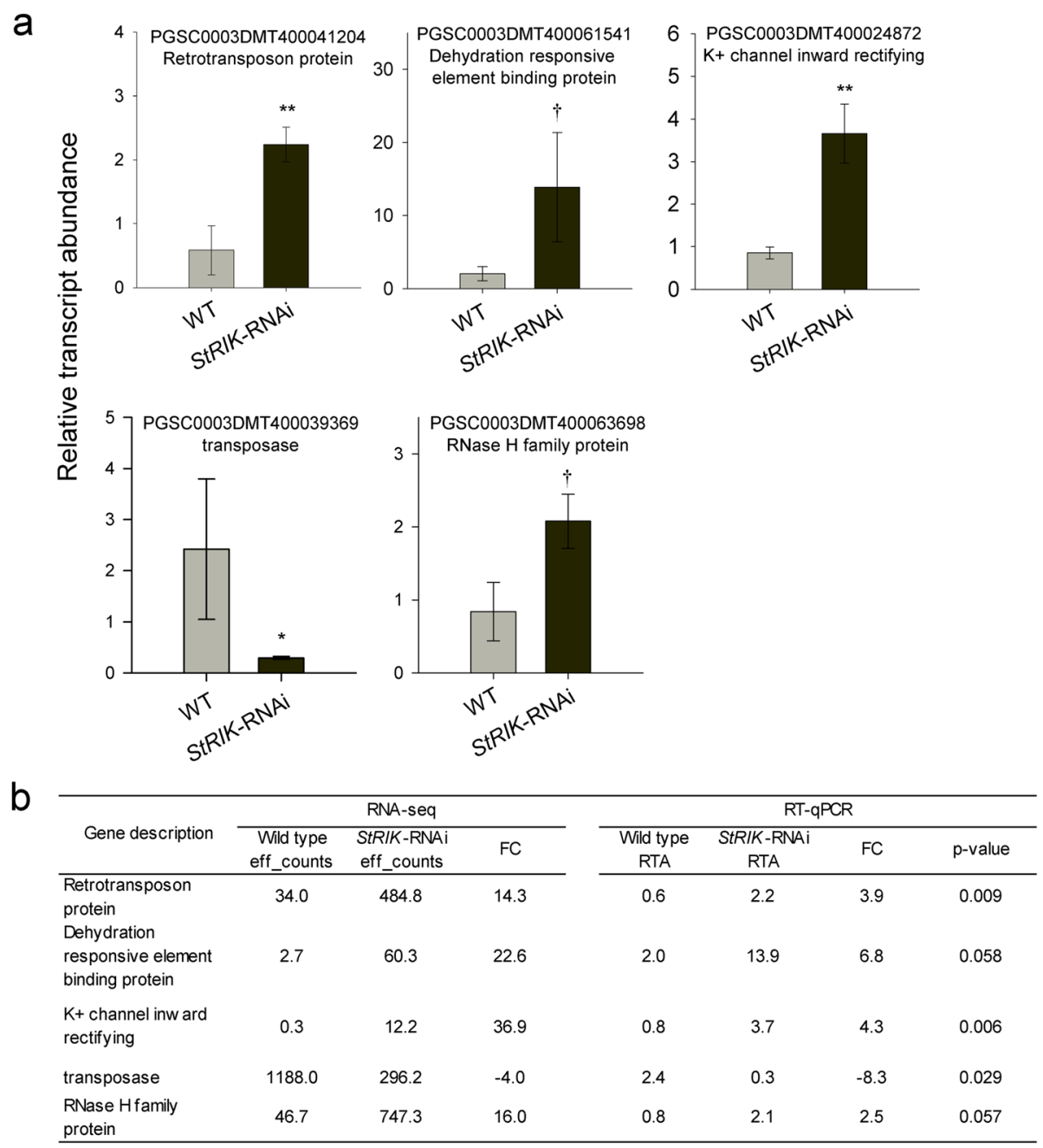

Fig. 5 RT-qPCR analysis in StRIK-RNAi and Wild type tuber periderm of five DEGs. a The relative transcript abundance (RTA) of Retrotransposon protein, Dehydration responsive element binding protein, $K+$ channel inward rectifying, transposase and RNase $H$ family protein, in StRIK deficient and Wild type lines is shown. Values are the mean \pm SD of the Wild type (three biological replicates, $n=3$ ) and StRIK-RNAi lines 12 and 47 (two biological replicates for each line, $n=4$ ). The three lines were compared using a one-way analysis of variance with contrasts that showed no statistically significant difference between the two silenced lines for any of the five genes. However, after Benjamini-Hochberg adjustment for multiple testing, the difference between the mean of the two silenced lines and the wild type was statistically significant or of borderline significance for all five genes (two asterisks $\left(* *, P<0.01\right.$ ), one asterisk $\left({ }^{*}, P<0.05\right)$ and dagger $(\dagger, P<0.06)$ ). $\mathbf{b}$ Comparison of the results obtained for these genes in the RNA-seq and the Real-time PCR analyses. Results show the transcript abundance estimated by each method (effective counts for RNA-seq and RTA for RT-qPCR) as well as the log2 Fold Change (FC) obtained

RNAi periderm (Table S2). Interestingly, CASPL4D1, which is very similar to CASPL4D2, is required for pathogeninduced lignification [61]. It is noteworthy that CASPL4C1, which is in the same gene subfamily as CASPL4D2 [62], showed earlier flowering and higher tolerance to cold stress when knocked out [63].

\section{Conclusions}

Basing on the cork upregulation versus wood of the cork oak RIK, we focused on the function of the StRIK in the periderm by a reverse genetic approach in potato.
Results showed that StRIK is encoded by a single gene in potato, as Arabidopsis and maize, contains two SF1like K-homology RNA binding domains and displays a nuclear localization. The transcript accumulated in all the constitutive tissues and was induced by wounding in potato tuber. StRIK downregulation correlated with flower development solely in transgenic lines, while no evident changes in periderm anatomy were found. Nonetheless, transcriptome analysis highlighted 101 genes differentially expressed between StRIK-RNAi and Wild type periderm lines, which belong to functions related to RNA metabolism, stress, transposable elements and 
signaling. Altogether, results suggest that StRIK might play a regulatory role in potato tuber periderm through stress signaling and RNA metabolism.

\section{Methods}

\section{Plant material}

The potato plant cultivar (S. tuberosum Group Tuberosum cv. Désirée) was kindly provided by Professor Salomé Prat (Center for Research in Agricultural Genomics: CRAG, Barcelona, Spain). The tetraploid potato cultivar Désirée was obtained from crossing Urgenta $x$ Depesche cultivars by ZPC breeder (Holland). The information of Désirée cultivar is available at the Potato Pedigree database (https://www.plantbreeding.wur.nl/ PotatoPedigree/lookup.php? name=DESIREE:\% 2 Oidentifier\%2011213, Wageningen University) and the European Cultivated Potato Database (ECPD: https:// www.europotato.org/varieties/view/Desiree-E). Potato tuber periderm was used to isolate the StRIK full-length coding sequence, to produce the StRIK silenced plants to perform reverse transcription followed by quantitative PCR (RT-qPCR) and RNA-seq experiments. To obtain Désirée tubers, in vitro plants were propagated as described by Serra et al. [64] and then transferred to soil and grown for 3 months in a walk-in chamber before tuber harvest. The skin of potato tuber was manually dissected using sterile scalpels and was immediately frozen in liquid nitrogen. When the phellogen is active it is prone to break, hence the skin is easily removed and the tissue recovered contains mainly phellem but also phellogen. From now on, we will use the term periderm to refer to the potato skin harvested that contains phellem and phellogen. Potato tubers of $S$. tuberosum Group Tuberosum cv. Monalisa were purchased in a local supermarket and used to study the StRIK responsiveness to wounding. To that aim, potato tuber discs $(3 \mathrm{~mm}$ thick and $13 \mathrm{~mm}$ in diameter) from flesh (parenchyma) were obtained with a cork borer and were left in a plastic box at room temperature, in darkness and saturated humidity conditions until sample harvesting.

\section{Cloning and sequencing the full-length of StRIK}

For complete coding sequence isolation, first strand cDNA was synthesized using SuperScript III reverse transcriptase (Invitrogen, http://www.invitrogen.com/), oligo $(\mathrm{dT})_{18}$ primer and total RNA from periderm tissue [65] previously treated with DNAse. The primers used to clone the full-length coding sequence of potato StRIK gene (Table S5) were designed based on the information from the potato Expressed Sequence Tag assembly (TC127409 and TC155463). PCR was performed using tuber periderm $\mathrm{CDNA}$ and the high fidelity PrimeSTAR ${ }^{\circ}$ HS DNA Polymerase (Takara). PCR product was cloned into pCR4-TOPO (Invitrogen) and sequenced using
BigDye [66] Terminator 3.1 kit (Applied Biosystems). The GenBank accession number of StRIK full-length coding sequence is MT622318.

\section{Potato transformation}

The hairpin RNAi construct for StRIK gene silencing was obtained by PCR amplification (Table S5) of a specific fragment of $246 \mathrm{bp}$ (Fig. S3). Amplification products were first cloned into pENTR/D-TOPO vector (Life Technologies) and then transferred in opposite orientations into the binary destination vector pBIN19RNAi [67] by LR clonase II enzyme (Life Technologies). Potato plant transformation was carried out as described by Fernández-Piñán et al. [66]. In brief, A. tumefaciens (GV2260) was transformed with the recombinant pBIN19RNAi vector and used to infect leaf explants, which were treated with phytohormones to induce the organogenesis process leading to kanamycin-resistant potato plants with the StRIK gene downregulated.

\section{Reverse transcription and quantitative PCR analysis (RT-qPCR)}

Total RNA was isolated following the protocol reported by Logemann et al. [65]. First-strand cDNA was synthesized from $2 \mu \mathrm{g}$ of DNAse digested RNA using the High Capacity cDNA Reverse Transcription kit (Applied Biosystems). Real time PCR analyses were performed in a LightCycler 96 Real-Time PCR System (Roche). Genespecific primers were designed with Primer3 0.4.0 software (https://bioinfo.ut.ee/primer3-0.4.0/) and then checked with NetPrimer (http://www.premierbiosoft. com/netprimer/). Each $20 \mu \mathrm{l}$ qPCR reaction contained $10 \mu \mathrm{l}$ of SYBR Green Select Master Mix (Applied Biosystems), $300 \mathrm{nM}$ of each forward and reverse corresponding primer and $5 \mu \mathrm{l}$ of a 100 -fold diluted cDNA. The thermal cycle program used was a first step of $95^{\circ} \mathrm{C}$ for $10 \mathrm{~min}$ and 40 cycles of $95^{\circ} \mathrm{C}$ for $10 \mathrm{~s}, 60^{\circ} \mathrm{C}$ for $15 \mathrm{~s}$ and $72^{\circ} \mathrm{C}$ for $10 \mathrm{~s}$. A dissociation final step was included to verify the presence of a single amplicon. For each primer pair, standard curves with a five-fold dilutions series of Wild type periderm cDNA template $(1 / 5,1 / 25,1 / 125,1 /$ 625 and 1/3125) was used to determine amplification efficiency, $E=10^{(-1 / \text { slope })}$. The mRNA abundances for each gene were calculated as relative transcript abundance $=\left(\mathrm{E}_{\text {target }}\right)^{\Delta \mathrm{Ct} \text { target (control-sample) }} /\left(\mathrm{E}_{\text {reference }}\right)^{\Delta \mathrm{Ct} \text { refer- }}$ ence (control-sample) [68]. cDNA control sample for native tissues analysis was a pool with equal amounts of all samples, for wounding stress assay a pool of $144 \mathrm{~h}$ postwounding replicates and for transgenic lines and RNAseq validation, a pool of Wild type periderm replicates. The housekeeping gene adenine phosphoribosyl transferase (APRT) was used to normalize the results, except for the wounding experiment in which the constitutive gene Elongation Factor $1 \alpha(E F 1 \alpha)$ was used [69]. Gene-specific primer sequences are available in Table $\mathrm{S} 5$. 


\section{Protein sequence alignment analysis}

The amino acid multisequence alignment was performed using the Clustal Omega program from the European Bioinformatics Institute (EBI, https://www.ebi.ac.uk/ Tools/msa/clustalo/). The alignment was edited using BOXSHADE version 3.21 available at https://embnet. vital-it.ch/software/BOX_form.html.

\section{Subcellular localization of RFP-StRIK fusion protein and periderm microscopy}

StRIK gene coding region was amplified with specific primers bearing the attB recombinant sequences at $5^{\prime}$ end (Table S5) using PrimeSTAR ${ }^{\bullet}$ HS DNA Polymerase (Takara). The amplicon was cloned into the GATEWAY donor vector pDONR207 ${ }^{\mathrm{Tm}}$ (Life Technologies) and then transferred into the destination vector pK7WGR2.0 [70] to fuse the RFP to the N-terminal end of StRIK (pK7WGR2.0-RIK). A. tumefaciens cells (GV3101) transformed with the pK7WGR2.0-RIK vector and the HcPro silencing suppressor [71] were grown in parallel overnight at $28^{\circ} \mathrm{C}$ in YEB liquid medium supplemented with the appropriate antibiotics. The cultures were centrifuged at $4000 \mathrm{~g}$, the cell pellet resuspended in infiltration buffer (10 mM MES (pH 5.6), $10 \mathrm{mM} \mathrm{MgCl}_{2}$ and $500 \mu \mathrm{M}$ acetosyringone) at 2 unit $\mathrm{OD}_{600} / \mathrm{ml}$ each culture and the mixture was incubated at room temperature for $2 \mathrm{~h}$. Before agroinfiltration, both Agrobacterium samples (RFP$R I K$ and HcPro) were mixed in a 1:1 ratio to achieve 1 unit $\mathrm{OD}_{600} / \mathrm{ml}$ each culture. This mixture was used to agroinfiltrate the abaxial side of $N$. benthamiana. After 3 days, transformed cells were observed under a NIKON Ti Eclipse fluorescence inverted microscope with a confocal unit NIKON A1R. To detect red fluorescence, leaves were excited at $543.5 \mathrm{~nm}$ wavelength and the emission was collected at $595 \mathrm{~nm}$. The software used for microscope imaging was NIKON NIS-Elements AR v 4.10. The scanning electron microscopy (SEM) was used to analyze the periderm anatomy as previously reported by Serra et al. [67] using 21-d stored tubers.

\section{RNA-seq high-throughput sequencing}

Periderm (skin) was isolated from freshly harvested potato tubers avoiding the underlying cortical parenchyma (see Plant Material subsection). Total RNA was purified by means of the PureLink ${ }^{\circ}$ Plant RNA Reagent (Ambion) using a modification of the standard protocol by repeating step four and five of the protocol twice and adding a KOAc $2 \mathrm{M}$ ( $\mathrm{pH} 5.5$ ) precipitation step to remove polysaccharides. Final RNA precipitation was performed with the GlycoBlue ${ }^{\mathrm{Tm}}$ Coprecipitant (Ambion). Genomic DNA was removed using TURBO DNA-free kit (Ambion) according to the manufacturer's instructions. RNA samples were analyzed using Agilent 2100 Bioanalyzer and those with an RNA integrity number (RIN) over 7 were sequenced. Three biological replicates were sequenced for each line (Wild type and StRIK-RNAi lines 9, 12 and 47). The cDNA libraries were prepared using the TruSeq RNA Library Prep Kit (Illumina) following the manufacturer's protocols and then ran in an Illumina HiSeq 2000 instrument (BGI Hong Kong). The quality of the RNAseq data was analyzed using FastQC v0.11.2 (https:// www.bioinformatics.babraham.ac.uk/projects/fastqc/).

The reads were aligned with Bowtie 2 [72] against the $S$. tuberosum Group Phureja transcriptome generated from the genome assembly v4.03 [30] using the most recent version of the GFF3 genome annotation file (PGSC_ DM_V403_genes.gff.zip) with the program gffread from the Cufflinks package [73]. The quantification of transcript abundance was performed with eXpress 1.5.1 [74]. The column labelled 'eff_counts' obtained from the eXpress output was passed as input to baySeq [75] for the differential expression analysis. For each model fitted, transcripts with a False Discovery Rate (FDR) less than 0.05 were considered differentially expressed. All sequencing data are available in the Gene Expression Omnibus repository from NCBI under accession code GSE153641.

\section{Abbreviations}

AS1: Asymmetric leaves 1; DEGs: Differentially expressed genes; GO: Gene ontology; KH: K-homology; rs2: Rough sheath2; RIK: Rs2-interacting KH protein; SF1: Splicing factor 1; RFP: Red fluorescent protein

\section{Supplementary Information}

The online version contains supplementary material available at https://doi. org/10.1186/s12870-021-03141-z.

Additional file 1: Fig. $\mathbf{S 1}$ Amino acid alignment of the potato ( $S$. tuberosum Group Tuberosum) StRIK protein with the most homologous proteins of S. tuberosum Group Phureja (PGSC0003DMP400043638), S. lycopersicum and S. pennellii (XP_004233384.1 and XP_015065578.1), Arabidopsis (AAY24687.1) and maize (AAY24682.1). The Arabidopsis splicing factor 1 SF1-like, At5g51300, identified by Lorkovic and Barta (2002) as KH domain protein, and the two most homologous proteins in potato PGSC0003DMP40003285 and PGSC0003DMP400012836 (designated as S.tubPhurSF1_1 and S.tubPhurSF1_2, respectively) are also included. The two predicted SF1_like-KH conserved protein domains and the highly conserved $\mathrm{KH}$ domain core consensus sequence $\| G \times x \mathrm{G} \times \mathrm{x}$ I described by Burd and Dreyfuss [21] are indicated. The proline-rich region identified is also shown. The amino acids that are identical are shaded in black and the ones that are similar in grey. The following abbreviations were used for the RIK and SF1 sequences: S.tub, S. tuberosum Group Tuberosum; S.tubPhur, S. tuberosum Group Phureja; S.lyc, S. Iycopersicum; S.pen, S. pennelli;; Arab, Arabidopsis; Z.may, Z. mays.

Additional file 2: Fig. S2 Transcript accumulation profile of StRIK and S. phureja RIK in different tissues and conditions. (a) Relative transcript abundance (RTA) of StRIK accumulation in different potato organs and tissues, RTA levels were expressed as the mean \pm SD of three technical replicates. (b) Transcript profile of RIK in S. phureja (DM and RH genotypes). The FPKM values were obtained from data reported by the Potato Genome Sequencing Consortium [30] and Massa et al. (2011). A red-green colour gradient from lower and higher transcript accumulation is shown, respectively. (c) Accumulation of StRIK transcripts in potato tuber healing discs over $144 \mathrm{~h}$. RTA levels are represented as the mean \pm SD of two biological replicates. There was a highly significant linear 
increase in StRIK levels after wounding (regression analysis to test linear relationship between transcript abundance and time: $p<0.001$ ).

Additional file 3: Fig. $\mathbf{S 3}$ Genomic StRIK sequence. Nucleotide sequence used for StRIK silencing is shown in red characters. The 12 exons of StRIK gene are shadowed in grey. The start initiation and the STOP codons are highlighted in green.

Additional file 4: Fig. S4 Target region of the $246 \mathrm{bp}$ StRIK-RNAi fragment underlined in grey on the RIK gene (PGSC0003DMG400025145) genomic sequence visualized in the Spub DB Genome Browser (http:// solanaceae.plantbiology.msu.edu/cgi-bin/gbrowse/potato/) from the [30]. The RIK gene is encoded in chromosome 2 antisense strand (-) between 25,304,888-25,313,841 bp positions in the S. tuberosum Group Phureja and it is composed of 12 exons and 11 introns which transcribes for four predicted gene isoforms. The StRIK-RNAi fragment targets exon 8, 9 and 10 from the representative transcript (PGSC0003DMT400064730) as well as two other gene isoforms PGSC0003DMT400064729 and

PGSC0003DMT400064731 while the fourth and shortest isoform PGSC0003DMT400064735 is not targeted by the RNAi fragment.

Additional file 5: Fig. S5 StRIK transcript accumulation measured by RT-qPCR in potato a) leaf and b) tuber periderm of StRIK-RNAi and Wild type lines from two consecutive plantings. Each column represents the mean and standard deviation of three technical replicates. Lines selected in leaves for further testing in tuber periderm are indicated with a red arrow.

Additional file 6: Table S1 BLASTN results against potato transcript database with the StRIK-RNAi construct as a query.

Additional file 7: Table S2 RNA-seq results of genes showing differential expression between Wild type and StRIK-RNAi potato tuber periderm (FDR < 0.05). Gene functional annotation of potato and Arabidopsis (e value $\leq 10^{-5}$ ), gene expression levels (effective counts) and $\log _{2} \mathrm{FC}$ values (StRIK-RNAi/WT) are shown.

Additional file 8: Table $\mathbf{S 3}$ List of the 300 most co-expressed genes with Arabidopsis RIK gene based on ATTED-II database (https://atted.jp/). Co-expression degree is represented as Mutual Rank (MR) value.

Additional file 9: Table $\mathbf{S 4}$ Gene ontology of 300 most co-expressed genes with RIK gene in Arabidopsis by PlantGSEA web tool (http:// structuralbiology.cau.edu.cn/PlantGSEA/index.php).

Additional file 10: Table S5 List of primers used.

\section{Acknowledgments}

The authors thank Prof. M. Molinas (Biology Department, UdG, Girona) for providing the SEM images and for her fruitful advice and feedback during the analysis of transcriptome data. We are also grateful to T. Hardcastle and B. Santos for their support in the bioinformatics analyses of RNA-seq data (Department of Plant Sciences, University of Cambridge, Cambridge), to S. Gómez (Biology Department, UdG, Girona) for their valuable assistance in carrying out the laboratory work and taking care of plants and to N. Pibernat for helping in the subcellular location of StRIK. We also thank to Professor C. Pla (Biology Department, UdG, Girona) for kindly lending the Thermocycler.

\section{Authors' contributions}

$\mathrm{PB}, \mathrm{MS}, \mathrm{KK}, \mathrm{OS}$ and MF conceived and designed the experiment; MS cloned the full-length and generated StRIK-RNAi transgenic plants; SFP performed subcellular localization of RFP-StRIK fusion protein, PB extracted the RNA and purified the mRNA; PB, SM, KK performed bioinformatics analyses; PB and XT performed APCR; all authors analyzed and discussed the data. PB and MF wrote the manuscript, all authors contributed and approved the manuscript.

\section{Funding}

This work was supported by the Ministerio de Educación y Ciencia (AGL200607342: identification of the gene and obtention of the transgenic lines), the Ministerio de Innovación y Ciencia [AGL2009-13745, FPI grant to P.B.:

Transcript profile of the gene in potato, selection of the transgenic lines], the Ministerio de Economía y Competitividad [AGL2012-36725; AGL2015-67495C2-1-R: analysis of the periderm anatomy, periderm transcriptome and cell localization of the protein], Departament d'Universitats, Investigació i Societat de la Informació de Catalunya [PhD grant to M.S.], the University of Girona [PhD grant to S.F.-P], The European Regional Development Fund (ERDF) and PID2019-110330GB-C21 (MCI/AEI/FEDER, UE).

\section{Availability of data and materials}

The StRIK full-length coding sequence is in the GenBank: accession number MT622318 (https://www.ncbi.nlm.nih.gov/genbank/). The RNA-seq data generated during the current study have been deposited in the Gene Expression Omnibus repository from NCBI under accession code GSE153641 (https:// www.ncbi.nlm.nih.gov/geo/query/acc.cgi?acc=GSE153641). Databases and programs used in this study are the following: Arabidopsis Information Resource (https://www.arabidopsis.org/), Spud DB Potato Genomics Resources (http://solanaceae.plantbiology.msu.edu/pgsc_download.shtml), ATTED-II (https://atted.jp/) Plant GeneSet Enrichment Analysis Toolkit database (http:// structuralbiology.cau.edu.cn/PlantGSEA/index.php) FastQC v0.11.2 (https:// www.bioinformatics.babraham.ac.uk/projects/fastqc/), Clustal Omega program from the European Bioinformatics Institute (EBI, https://www.ebi.ac.uk/ Tools/msa/clustalo/), BOXSHADE version 3.21 (https://embnet.vital-it.ch/ software/BOX_form.html), Primer3 0.4.0 software (https://bioinfo.ut.ee/ primer3-0.4.0/), NetPrimer (http://www.premierbiosoft.com/netprimer/), Potato Pedigree database (https://www.plantbreeding.wur.nl/PotatoPedigree/ lookup.php?name=DESIREE:\%20identifier\%2011213) and the European Cultivated Potato Database (ECPD: https://www.europotato.org/varieties/view/ Desiree-E). Public access to all these databases is open. The material used in this study will be shared on reasonable request to the corresponding author.

\section{Declarations}

\section{Ethics approval and consent to participate}

The laboratory has a license approved by the Ministerio de Agricultura, Alimentación y Medio Ambiente to develop type 1 activities for GMOs under confined use.

\section{Consent for publication}

Not applicable.

\section{Competing interests}

The authors declare that they have no competing interests.

\section{Author details}

'Laboratori del Suro, Biology Department, Universitat de Girona, Campus Montilivi, E-17071 Girona, Catalonia, Spain. '2Department of Plant Sciences, University of Cambridge, Downing Street, Cambridge CB2 3EA, UK.

Received: 21 January 2021 Accepted: 6 July 2021

Published online: 07 September 2021

\section{References}

1. Lendzian KJ. Survival strategies of plants during secondary growth: barrier properties of phellems and lenticels towards water, oxygen, and carbon dioxide. J Exp Bot. 2006;57(11):2535-46. https://doi.org/10.1093/jxb/erl014.

2. Campilho A, Nieminen K, Ragni L. The development of the periderm: the final frontier between a plant and its environment. Curr Opin Plant Biol. 2020;53:10-4. https://doi.org/10.1016/.jpbi.2019.08.008.

3. Ranathunge $K$, Schreiber L, Franke R. Suberin research in the genomics eranew interest for an old polymer. Plant Sci. 2011;180(3):399-413. https://doi. org/10.1016/j.plantsci.2010.11.003.

4. Alonso-Serra J, Safronov O, Lim K, Fraser-Miller SJ, Blokhina OB, Campilho A, et al. Tissue-specific study across the stem reveals the chemistry and transcriptome dynamics of birch bark. New Phytol. 2019;222(4):1816-31. https://doi.org/10.1111/nph.15725.

5. Boher P, Soler M, Sánchez A, Hoede C, Noirot C, Paiva JAP, et al. A comparative transcriptomic approach to understanding the formation of cork. Plant Mol Biol. 2018;96(1-2):103-18. https://doi.org/10.1007/s11103-0170682-9.

6. Rains MK, Gardiyehewa de Silva ND, Molina I. Reconstructing the suberin pathway in poplar by chemical and transcriptomic analysis of bark tissues. Tree Physiol. 2018;38(3):340-61. https://doi.org/10.1093/treephys/tpx060.

7. Soler M, Serra O, Molinas M, Huguet G, Fluch S, Figueras M. A genomic approach to suberin biosynthesis and cork differentiation. Plant Physiol. 2007;144(1):419-31. https://doi.org/10.1104/pp.106.094227.

8. Teixeira RT, Fortes AM, Bai H, Pinheiro C, Pereira H. Transcriptional profiling of cork oak phellogenic cells isolated by laser microdissection. Planta. 2018; 247(2):317-38. https://doi.org/10.1007/s00425-017-2786-5. 
9. Teixeira RT, Fortes AM, Pinheiro C, Pereira H. Comparison of good- and badquality cork: application of high-throughput sequencing of phellogenic tissue. J Exp Bot. 2014;65(17):4887-905. https://doi.org/10.1093/jxb/eru252.

10. Vulavala VKR, Fogelman E, Faigenboim A, Shoseyov O, Ginzberg I. The transcriptome of potato tuber phellogen reveals cellular functions of cork cambium and genes involved in periderm formation and maturation. Sci Rep. 2019;9(1):10216. https://doi.org/10.1038/s41598-019-46681-z.

11. Vulavala VKR, Fogelman E, Rozental L, Faigenboim A, Tanami Z, Shoseyov O, et al. Identification of genes related to skin development in potato. Plant Mol Biol. 2017;94(4-5):481-94. https://doi.org/10.1007/s11103-017-0619-3.

12. Lopes ST, Sobral D, Costa B, Perdiguero P, Chaves O, Costa A, et al. Phellem versus xylem: genome-wide transcriptomic analysis reveals novel regulators of cork formation in cork oak. Tree Physiol. 2020;40(2):129-41. https://doi. org/10.1093/treephys/tpz118

13. Capote T, Barbosa P, Usié A, Ramos AM, Inácio V, Ordás R, et al. ChIP-Seq reveals that QsMYB1 directly targets genes involved in lignin and suberin biosynthesis pathways in cork oak (Quercus suber). BMC Plant Biol. 2018; 18(1):198. https://doi.org/10.1186/s12870-018-1403-5.

14. Mahmood K, Zeisler-Diehl W, Schreiber L, Bi Y-M, Rothstein SJ, Ranathunge K. Overexpression of ANAC046 promotes Suberin biosynthesis in roots of Arabidopsis thaliana. Int J Mol Sci. 2019;20(24):6117. https://doi.org/10.3390/ ijms20246117.

15. Soler $\mathrm{M}$, Verdaguer $\mathrm{R}$, Fernández-Piñán $\mathrm{S}$, Company-Arumí $\mathrm{D}$, Boher $\mathrm{P}$, Góngora-Castillo E, et al. Silencing against the conserved NAC domain of the potato StNAC103 reveals new NAC candidates to repress the suberin associated waxes in phellem. Plant Sci. 2020;291:110360. https://doi.org/10.1 016/j.plantsci.2019.110360.

16. Verdaguer R, Soler M, Serra O, Garrote A, Fernández S, Company-Arumí D, et al. Silencing of the potato StNAC103 gene enhances the accumulation of suberin polyester and associated wax in tuber skin. J Exp Bot. 2016;67(18): 5415-27. https://doi.org/10.1093/jxb/erw305.

17. Phelps-Durr TL, Thomas J, Vahab P, Timmermans MCP. Maize rough sheath2 and its Arabidopsis orthologue ASYMMETRIC LEAVES1 interact with HIRA, a predicted histone chaperone, to maintain Knox gene silencing and determinacy during organogenesis. Plant Cell. 2005;17(11):2886-98. https:// doi.org/10.1105/tpc.105.035477.

18. Guo M, Thomas J, Collins G, Timmermans MCP. Direct repression of KNOX loci by the ASYMMETRIC LEAVES1 complex of Arabidopsis. Plant Cell. 2008; 20(1):48-58. https://doi.org/10.1105/tpc.107.056127.

19. Li Z, Li B, Liu J, Guo Z, Liu Y, Li Y, et al. Transcription factors AS1 and AS2 interact with LHP1 to repress KNOX genes in Arabidopsis. J Integr Plant Biol. 2016;58(12):959-70. https://doi.org/10.1111/jipb.12485.

20. Lodha M, Marco CF, Timmermans MCP. The ASYMMETRIC LEAVES complex maintains repression of KNOX homeobox genes via direct recruitment of Polycomb-repressive complex2. Genes Dev. 2013;27(6):596-601. https://doi. org/10.1101/gad.211425.112.

21. Burd CG, Dreyfuss $G$. Conserved structures and diversity of functions of RNA-binding proteins. Science. 1994;265(5172):615-21. https://doi.org/1 $0.1126 /$ science.8036511.

22. Lorković ZJ, Barta A. Genome analysis: RNA recognition motif (RRM) and K homology $(\mathrm{KH})$ domain RNA-binding proteins from the flowering plant Arabidopsis thaliana. Nucleic Acids Res. 2002;30(3):623-35. https://doi.org/1 0.1093/nar/30.3.623.

23. Buckner B, Swaggart KA, Wong CC, Smith HA, Aurand KM, Scanlon MJ, et al. Expression and nucleotide diversity of the maize RIK gene. J Hered. 2008; 99(4):407-16. https://doi.org/10.1093/jhered/esn013.

24. Cheng Y, Kato N, Wang W, Li J, Chen X. Two RNA binding proteins, HEN4 and HUA1, act in the processing of AGAMOUS pre-mRNA in Arabidopsis thaliana. Dev Cell. 2003;4(1):53-66. https://doi.org/10.1016/S1534-5807(02)00399-4.

25. Lim M-H, Kim J, Kim Y-S, Chung K-S, Seo Y-H, Lee I, et al. A new Arabidopsis gene, FLK, encodes an RNA binding protein with K homology motifs and regulates flowering time via FLOWERING LOCUS C. Plant Cell. 2004;16(3): 731-40. https://doi.org/10.1105/tpc.019331.

26. Vega-Sánchez ME, Zeng L, Chen S, Leung H, Wang G-L. SPIN1, a K homology domain protein negatively regulated and ubiquitinated by the E3 ubiquitin ligase SPL11, is involved in flowering time control in rice. Plant Cell. 2008;20(6):1456-69. https://doi.org/10.1105/tpc.108.058610.

27. Ripoll JJ, Ferrándiz C, Martínez-Laborda A, Vera A. PEPPER, a novel Khomology domain gene, regulates vegetative and gynoecium development in Arabidopsis. Dev Biol. 2006;289(2):346-59. https://doi.org/10.1016/j.ydbio.2 005.10.037.
28. Jiang J, Wang B, Shen Y, Wang H, Feng Q, Shi H. The Arabidopsis RNA binding protein with $\mathrm{K}$ homology motifs, SHINY1, interacts with the Cterminal domain phosphatase-like 1 (CPL1) to repress stress-inducible gene expression. PLoS Genet. 2013;9(7):e1003625. https://doi.org/10.1371/journal. pgen. 1003625.

29. Thatcher LF, Kamphuis LG, Hane JK, Oñate-Sánchez L, Singh KB. The Arabidopsis $\mathrm{KH}$-domain RNA-binding protein ESR1 functions in components of Jasmonate Signalling, unlinking growth restraint and resistance to stress. PLoS One. 2015;10(5):e0126978. https://doi.org/10.1371/journal.pone.0126978.

30. Potato Genome Sequencing Consortium. Genome sequence and analysis of the tuber crop potato. Nature. 2011;475(7355):189-95. https://doi.org/10.103 8/nature10158.

31. Marchler-Bauer A, Zheng C, Chitsaz F, Derbyshire MK, Geer LY, Geer RC, et al. CDD: conserved domains and protein three-dimensional structure. Nucleic Acids Res. 2013;41(D1):348-52. https://doi.org/10.1093/nar/gks1243.

32. Ivanov S, Harrison MJ. A set of fluorescent protein-based markers expressed from constitutive and arbuscular mycorrhiza-inducible promoters to label organelles, membranes and cytoskeletal elements in Medicago truncatula. Plant J. 2014;80(6):1151-63. https://doi.org/10.1111/tpj.12706.

33. Aoki Y, Okamura Y, Tadaka S, Kinoshita K, Obayashi T. ATTED-II in 2016: a plant Coexpression database towards lineage-specific Coexpression. Plant Cell Physiol. 2016;57(1):e5. https://doi.org/10.1093/pcp/pcv165.

34. Yi X, Du Z, SU Z. PlantGSEA: a gene set enrichment analysis toolkit for plant community. Nucleic Acids Res. 2013;41(W1):98-103. https://doi.org/10.1093/ nar/gkt281.

35. Rodríguez-Cazorla E, Ripoll JJ, Andújar A, Bailey $\sqcup$, Martínez-Laborda A, Yanofsky MF, et al. K-homology nuclear ribonucleoproteins regulate floral organ identity and determinacy in arabidopsis. PLoS Genet. 2015;11(2): e1004983. https://doi.org/10.1371/journal.pgen.1004983.

36. Ripoll JJ, Rodríguez-Cazorla E, González-Reig S, Andújar A, AlonsoCantabrana H, Perez-Amador MA, et al. Antagonistic interactions between Arabidopsis K-homology domain genes uncover PEPPER as a positive regulator of the central floral repressor FLOWERING LOCUS C. Dev Biol. 2009:333(2):251-62. https://doi.org/10.1016/..ydbio.2009.06.035.

37. Winter $D$, Vinegar B, Nahal H, Ammar R, Wilson GV, Provart NJ. An "electronic fluorescent pictograph" browser for exploring and analyzing large-scale biological data sets. PLoS One. 2007;2(8):e718. https://doi.org/1 0.1371/journal.pone.0000718.

38. Sakuma Y, Maruyama K, Qin F, Osakabe Y, Shinozaki K, Yamaguchi-Shinozaki K. Dual function of an Arabidopsis transcription factor DREB2A in water-stressresponsive and heat-stress-responsive gene expression. Proc Natl Acad Sci U S A. 2006;103(49):18822-7. https://doi.org/10.1073/pnas.0605639103.

39. Pilot G, Lacombe B, Gaymard F, Cherel I, Boucherez J, Thibaud JB, et al. Guard cell inward K+ channel activity in arabidopsis involves expression of the twin channel subunits KAT1 and KAT2. J Biol Chem. 2001:276(5):321521. https://doi.org/10.1074/jbc.M007303200.

40. Sutter JU, Sieben C, Hartel A, Eisenach C, Thiel G, Blatt MR. Abscisic acid triggers the endocytosis of the Arabidopsis KAT1 K+ channel and its recycling to the plasma Membrane. Curr Biol. 2007;17(16):1396-402. https:// doi.org/10.1016/j.cub.2007.07.020.

41. Klok EJ, Wilson IW, Wilson D, Chapman SC, Ewing RM, Somerville SC, et al. Expression profile analysis of the low-oxygen response in Arabidopsis root cultures. Plant Cell. 2002;14(10):2481-94. https://doi.org/10.1105/tpc.004747.a naerobiosis.

42. Botella M, XU Y, Prabha TN, Zhao Y, Narasimhan ML, Wilson KA, et al. Differential expression of soybean cysteine proteinase inhibitor genes during development and in response to wounding and methyl jasmonate. Plant Physiol. 1996;112(3):1201-10. https://doi.org/10.1104/pp.112.3.1201.

43. Bradshaw HD, Hollick JB, Parsons TJ, Clarke HR, Gordon MP. Systemically wound-responsive genes in poplar trees encode proteins similar to sweet potato sporamins and legume Kunitz trypsin inhibitors. Plant Mol Biol. 1990; 14(1):51-9. https://doi.org/10.1007/BF00015654.

44. Haruta M, Major IT, Christopher ME, Patton JJ, Constabel CP. A Kunitz trypsin inhibitor gene family from trembling aspen (Populus tremuloides Michx.): cloning, functional expression, and induction by wounding and herbivory. Plant Mol Biol. 2001:46(3):347-59. https://doi.org/10.1023/A:1010654711619.

45. Barel G, Ginzberg I. Potato skin proteome is enriched with plant defence components. J Exp Bot. 2008;59(12):3347-35. https://doi.org/10.1093/jxb/ ern184.

46. Soler M, Serra O, Fluch S, Molinas FM. A potato skin SSH library yields new candidate genes for suberin biosynthesis and periderm formation. Planta. 
2011;233(5):933-45. https://doi.org/10.1007/s00425-011-1350-y.Epub2011 Ja n20.

47. Barberon M, Vermeer JEM, De Bellis D, Wang P, Naseer S, Andersen TG, et al. Adaptation of root function by nutrient-induced plasticity of endodermal differentiation. Cell. 2016;164(3):447-59. https://doi.org/10.1016/j.cell.2015.12.021.

48. Cerritelli SM, Crouch RJ. Ribonuclease H: the enzymes in eukaryotes. FEBS J. 2009;276(6):1494-505. https://doi.org/10.1111/j.1742-4658.2009.06908.x.

49. Kellner $\mathrm{V}$, Luke B. Molecular and physiological consequences of faulty eukaryotic ribonucleotide excision repair. EMBO J. 2020;39(3):e102309. https://doi.org/10.15252/embj.2019102309.

50. Hotto AM, Castandet B, Gilet L, Higdon A, Condon C, Stern DB. Arabidopsis chloroplast mini-ribonuclease III participates in rRNA maturation and intron recycling. Plant Cell. 2015;27(3):724-40. https://doi.org/10.1105/tpc.114.134452.

51. Tian Y, Chen MX, Yang JF, Achala HHK, Gao B, Hao GF, et al. Genome-wide identification and functional analysis of the splicing component SYF2/ NTC31/p29 across different plant species. Planta. 2019;249(2):583-600. https://doi.org/10.1007/s00425-018-3026-3.

52. Macknight R, Bancroft I, Page T, Lister C, Schmidt R, Love K, et al. FCA, a gene controlling flowering time in arabidopsis, encodes a protein containing RNA-binding domains. Cell. 1997;89(5):737-45. https://doi.org/1 0.1016/S0092-8674(00)80256-1.

53. Domon C, Lorković ZJ, Vaicárcel J, Filipowicz W. Multiple forms of the U2 small nuclear ribonucleoprotein auxiliary factor U2AF subunits expressed in higher plants. J Biol Chem. 1998;273(51):34603-10. https://doi.org/10.1074/ jbc.273.51.34603.

54. Jang YH, Park HY, Lee KC, Thu MP, Kim SK, Suh MC, et al. A homolog of splicing factor SF1 is essential for development and is involved in the alternative splicing of pre-mRNA in Arabidopsis thaliana. Plant J. 2014;78(4): 591-603. https://doi.org/10.1111/tpj.12491

55. Park H-Y, Lee HT, Lee JH, Kim J-K. Arabidopsis U2AF65 regulates flowering time and the growth of pollen tubes. Front Plant Sci. 2019;10:569. https:// doi.org/10.3389/fpls.2019.00569.

56. Chen T, Cui P, Chen H, Ali S, Zhang S, Xiong L. A KH-domain RNA-binding protein interacts with FIERY2/CTD phosphatase-like 1 and splicing factors and is important for pre-mRNA splicing in Arabidopsis. PLoS Genet. 2013; 9(10):e1003875. https://doi.org/10.1371/journal.pgen.1003875.

57. Ito H. Small RNAs and transposon silencing in plants. Develop Growth Differ. 2012;54(1):100-7. https://doi.org/10.1111/j.1440-169X.2011.01309.x.

58. Oliver KR, McComb JA, Greene WK. Transposable elements: powerful contributors to angiosperm evolution and diversity. Genome Biol Evol. 2013; 5(10):1886-901. https://doi.org/10.1093/gbe/evt141.

59. Lisch D. Epigenetic regulation of transposable elements in plants. Annu Rev Plant Biol. 2009;60(1):43-66. https://doi.org/10.1146/annurev.arplant.59.032 607.092744.

60. Vishwanath SJ, Delude C, Domergue F, Rowland O. Suberin: biosynthesis, regulation, and polymer assembly of a protective extracellular barrier. Plant Cell Rep. 2015;34(4):573-86. https://doi.org/1 0.1007/s00299-014-1727-z.

61. Lee M, Jeon HS, Kim SH, Chung JH, Roppolo D, Lee H, et al. Lignin-based barrier restricts pathogens to the infection site and confers resistance in plants. EMBO J. 2019;38(23):38. https://doi.org/10.15252/embj.2019101948.

62. Roppolo D, Boeckmann B, Pfister A, Boutet E, Rubio MC, Dénervaud-Tendon $V$, et al. Functional and evolutionary analysis of the CASPARIAN STRIP MEMBRANE DOMAIN PROTEIN family. Plant Physiol. 2014;165(4):1709-22. https://doi.org/10.1104/pp.114.239137.

63. Yang J, Ding C, Xu B, Chen C, Narsai R, Whelan J, et al. A Casparian strip domain-like gene, CASPL, negatively alters growth and cold tolerance. Sci Rep. 2015;5(1):1-11. https://doi.org/10.1038/srep14299.

64. Serra O, Soler M, Hohn C, Franke R, Schreiber L, Prat S, et al. Silencing of StKCS6 in potato periderm leads to reduced chain lengths of suberin and wax compounds and increased peridermal transpiration. J Exp Bot. 2009a; 60(2):697-707. https://doi.org/10.1093/jxb/ern314.

65. Logemann J, Schell J, Willmitzer L. Improved method for the isolation of RNA from plant tissues. Anal Biochem. 1987;163(1):16-20. https://doi.org/1 0.1016/0003-2697(87)90086-8.

66. Fernández-Piñán S, López J, Armendariz I, Boher P, Figueras M, Serra O. Agrobacterium tumefaciens and Agrobacterium rhizogenes-mediated transformation of potato and the promoter activity of a Suberin gene by GUS staining. J Vis Exp. 2019;(145). https://doi.org/10.3791/59119.

67. Serra O, Soler M, Hohn C, Sauveplane V, Pinot F, Franke R, et al. CYP86A33targeted gene silencing in potato tuber alters suberin composition, distorts suberin lamellae, and impairs the periderm's water barrier function. Plant Physiol. 2009b;149(2):1050-60. https://doi.org/10.1104/pp.108.127183.

68. Pfaffl MW. A new mathematical model for relative quantification in real-time RT-PCR. Nucleic Acids Res. 2001;29(9):e45-445. https://doi.org/10.1093/nar/2 9.9.e45.

69. Nicot N, Hausman J-F, Hoffmann L, Evers D. Housekeeping gene selection for real-time RT-PCR normalization in potato during biotic and abiotic stress. J Exp Bot. 2005;56(421):2907-14. https://doi.org/10.1093/jxb/eri285.

70. Karimi M, Inzé D, Depicker A. GATEWAY vectors for Agrobacteriummediated plant transformation. Trends Plant Sci. 2002;7(5):193-5. https://doi. org/10.1016/S1360-1385(02)02251-3.

71. Llave C, Kasschau KD, Carrington JC (2000) Virus-encoded suppressor of posttranscriptional gene silencing targets a maintenance step in the silencing pathway. Proc Natl Acad Sci 97:13401-13406. 10.1073/pnas. 230334397, 24.

72. Langmead B, Salzberg SL. Fast gapped-read alignment with bowtie 2. Nat Methods. 2012;9(4):357-9. https://doi.org/10.1038/nmeth.1923.

73. Trapnell C, Roberts A, Goff L, Pertea G, Kim D, Kelley DR, et al. Differential gene and transcript expression analysis of RNA-seq experiments with TopHat and cufflinks. Nat Protoc. 2012;7(3):562-78. https://doi.org/10.1038/ nprot.2012.016.

74. Roberts A, Pachter L. Streaming fragment assignment for real-time analysis of sequencing experiments. Nat Methods. 2012;10(1):71-3. https://doi.org/1 0.1038/nmeth.2251.

75. Hardcastle TJ, Kelly KA. baySeq: empirical Bayesian methods for identifying differential expression in sequence count data. BMC Bioinformatics. 2010; 11(1):422. https://doi.org/10.1186/1471-2105-11-422.

\section{Publisher's Note}

Springer Nature remains neutral with regard to jurisdictional claims in published maps and institutional affiliations.

\section{Ready to submit your research? Choose BMC and benefit from:}

- fast, convenient online submission

- thorough peer review by experienced researchers in your field

- rapid publication on acceptance

- support for research data, including large and complex data types

- gold Open Access which fosters wider collaboration and increased citations

- maximum visibility for your research: over $100 \mathrm{M}$ website views per year

At $\mathrm{BMC}$, research is always in progress.

Learn more biomedcentral.com/submissions 